RASĀYAN J. Chem.

Vol. 13 | No. 4 |2401-2404| October - December | 2020 ISSN: 0974-1496 | e-ISSN: 0976-0083 | CODEN: RJCABP

\title{
PALM SLUDGE OIL AS RAW MATERIAL OF BIODIESEL SYNTHESIS THROUGH ELECTROLYSIS PROCESS USED Ag ELECTRODE
}

\author{
D. Irawan*, Z. Arifin, M. Gery and M.A. Fithia \\ Department of Chemical Engineering, Politeknik Negeri Samarinda, J1. Ciptomangunkusumo \\ Kampus Gn. Panjang, Samarinda-75131, (Kaltim) Indonesia \\ *E-mail: ddy_iwn@yahoo.com
}

\begin{abstract}
Palm Sludge Oil, PSO, is the low quality of palm oil whereas it changes to liquid waste at the factory. It could be synthesis into biodiesel through the electrolysis method with a Pt electrode. PSO will be descending free fatty acid with esterification. Furthermore, PSO transesterification changes to biodiesel of electron transfer way from the electrolysis process. Its electrolysis is used to Supply DC of 15 volts and correlated with two Ag electrodes. The process is having two variables, electrode distance of $1-2 \mathrm{~cm}$ and time process of $2.5-4$ hours. The highest yield of biodiesel proceeded electrode distances of $1.5 \mathrm{~cm}$ and took a transesterification time of 3.5 hours. The best yield resulted in $92.51 \%$.
\end{abstract}

Keywords: Biodiesel, Electrolysis, PSO, Electrode, Ag.

(C) RASĀYAN. All rights reserved

\section{INTRODUCTION}

Biodiesel is one of renewable energy and safe for the environment with diesel as fuel. It, one of the biodegradable fuel, is having low $\mathrm{CO}_{2}$ emission and low sulfuric gas. ${ }^{1}$ This circumstance can be to decrease the importing volume of crude oil as diesel fuel. Increasing of biodiesel is also adding Indonesia needed. Increasing biodiesel consumption needs process technology development and diversification. As a result, the raw material was being cheaper. This raw material is palm oil. Diversification of raw material gets low cost with oil-absorbing from wastewater of crude palm oil factory, it called Palm Sludge Oil (PSO). PSO is the low quality of palm oil with free fatty acid more than $20 \%{ }^{2}$ Indonesia was one of the highest Crude Palm Oil (CPO) manufacturers in 2015. PSO prediction resulted from manufacturing that is around $+/-30$ million tons/year. ${ }^{3} \mathrm{PSO}$ is having huge potency as a raw material of biodiesel. Biodiesel from PSO is having a good quality resemblance to be resulted by crude palm oil.

Biodiesel is conventionally made by homogeneous alkali catalysts, such as $\mathrm{NaOH}$ and $\mathrm{KOH}^{4}$ and acid catalysts of $\mathrm{H}_{2} \mathrm{SO}_{4}, \mathrm{HCl}^{5}$, and $\mathrm{H}_{3} \mathrm{PO}_{4}{ }^{6}$ Other than that, the raw material is having Free Fatty Acid (FFA) > $0.5 \%$ and water content $>0.06 \%$. Homogeneous alkali catalyst was several weaknesses such as saponification and catalyst consumption which has been decreasing efficiency for the whole process. Its process doesn't impact by FFA and water content.

The electrolysis method of biodiesel synthesis is having several benefits such as reduce energy consumption that process happened at ambient temperature, reduce water consumption until $90 \%$ of the biodiesel part, and it resulted in less waste. The key of this method is to make OH- ion at the cathode part and then it will be reacted with an alcohol to create an alkoxide ion. In the end, alkoxide ion reacted triglycerides and resulted in biodiesel. ${ }^{7-9}$

\section{EXPERIMENTAL}

\section{Materials}

The raw material is PSO were taken from CPO manufacture, Methanol p.a, Aquadest, $\mathrm{KOH}$ solid p.a, Alkali water, Phenolfthalein indicator, $\mathrm{KOH}$ solution $0,1 \mathrm{~N}, \mathrm{pH}$ indicator, $\mathrm{NaOH}$ solid p.a, $\mathrm{NaOH}$ solution $0.1 \mathrm{~N}$, $\mathrm{NaCl}$ solution $0.5 \mathrm{~N}, \mathrm{H}_{2} \mathrm{SO}_{4}$ solution $98 \%, \mathrm{Ag}$ plate with dimension $3 \times 2 \times 0.1 \mathrm{~cm}$. 
RASĀYAN J. Chem.

Vol. 13 | No. 4 |2401-2404| October - December | 2020

\section{Procedure}

\section{Raw Material Preparation}

PSO took from CPO manufacture which is filter and heat at a temperature of $105-110^{\circ} \mathrm{C}$ as long as 2 hours. Furthermore, it was repetitive to filter. PSO will be analyzed acidic value (AV) and saponification value (SV). It was used to analyze methods by Standard Nasional Indonesia (SNI) No. 01-35555-1998. It is supposed to calculate the average molecule weight (MW) from triglyceride. ${ }^{10}$

$$
\mathrm{MW}=56.1 \times 1000 \times \frac{3}{(\mathrm{SV}-\mathrm{AV})}
$$

FFA concentration is also based on SNI No. 01-3555-1998.

\section{Esterification}

It took PSO sample as many as 100 grams and added methanol of $94,3 \mathrm{~mL}$ (molar ratio oil - methanol of $1: 20$ ). On the other hand, it also added sulfate acid catalysts of $0,5 \mathrm{~mL}$. Doing reflux at temperature $60-$ $70^{\circ} \mathrm{C}$ and takes 90 minutes. After that, it separated between alkyl ester and water. To analyze alkyl ester and FFA concentration is less than 5\%. It continued transesterification by the electrolysis process.

\section{Electrolysis PSO}

It used power supply Direct Current (DC) at 15 volts and related with two Ag's electrodes of space variable $1-2 \mathrm{~cm}$. From the esterification process, PSO took 100 grams with measuring glass $250 \mathrm{~mL}$. The added solution of methanol - oil with a ratio of $6: 1$ and added $\mathrm{KOH}$ with a variation of $0.4-0.7 \% \mathrm{weight} / \mathrm{weight}$. To be pipe alkali water as $2 \%$ weight/weight and then aquadest is onto a solution of $\mathrm{KOH}$ and methanol. Turned electrolysis process as long as $2.5-4$ hours. After that process, the solution is separated from a funnel. This solution will be settling for around 2 hours which can be made into two layers, top layer, and bottom layer. The top layer is biodiesel crude. Next, it will be into the purification process.

\section{Purification}

To wash biodiesel crude used to hot aquadest with a volume ratio of 1:1. This process proceeded until $\mathrm{pH}$ achieves at $6.5-7$. Heating biodiesel which to separate methanol and aquadest at $110^{\circ} \mathrm{C}$. This way will be finished until not appear vesicle as a result of the heating process. After that yield of biodiesel gets until ambient temperature and measures volume.

\section{Analyze}

Biodiesel quality test used to kinematic viscosity at $40^{\circ} \mathrm{C}$ (SNI 7182:2015), the density of biodiesel at $40^{\circ} \mathrm{C}$ (SNI 7182:2015), Acidity value at $40^{\circ} \mathrm{C}$ (SNI 7182:2015), flash point and calculating yield of biodiesel ${ }^{8}$.

$$
\text { Biodiesel production yield }(\%)=\left(\frac{\text { weight of biodiesel }}{\text { Weight of oil }}\right) \times 100 \%
$$

\section{RESULTS AND DISCUSSION}

Biodiesel synthesis used PSO but this material should be previously esterification because of the huge FFA content. This esterification does avoid saponification at transesterification with the electrolysis method because it occupied alkali catalysts. Analyzing PSO after esterification in Table-1 is showing FFA content of less than 5\%. And then, it will work on transesterification through the electrolysis process.

Table-1: PSO Test Result after Esterification

\begin{tabular}{c|c|c|c|c}
\hline $\begin{array}{c}\text { Density } \\
\left(\mathrm{Kg} / \mathrm{m}^{3}\right)\end{array}$ & $\begin{array}{c}\text { Kinematic Viscosity } \\
(\mathrm{cSt})\end{array}$ & $\begin{array}{c}\text { Acid Value } \\
(\mathrm{mgKOH} / \mathrm{g})\end{array}$ & $\begin{array}{c}\text { Sapoon Value } \\
(\mathrm{mgKOH} / \mathrm{g})\end{array}$ & FFA (\%) \\
\hline 912.6 & 32.4264 & 7.8293 & 210.9336 & 2.56 \\
\hline
\end{tabular}

The Ag electrode to reduce cost on the biodiesel process is having relatively electricity conductivity more than the graphite electrode and platinum electrode. If it compares to the Fe electrode, the Ag electrode has a strong oxidizer and it can be effected hydroxyl ion creating on reduction reaction in electrolysis. ${ }^{9}$ 
RASĀYAN J. Chem.

Vol. 13 | No. 4 |2401-2404| October - December | 2020

\section{Electrode Distance Effect to Biodiesel Yield}

Transesterification of PSO on the electrolysis method gave the amount of electricity amount to triglyceride and methanol solution. Electricity energy flew to the Ag electrode which did oxidizer reaction and reduction reaction on that distance of electrode. A distance of electrode affected to a current of electricity as long as the electrolysis process. ${ }^{11}$

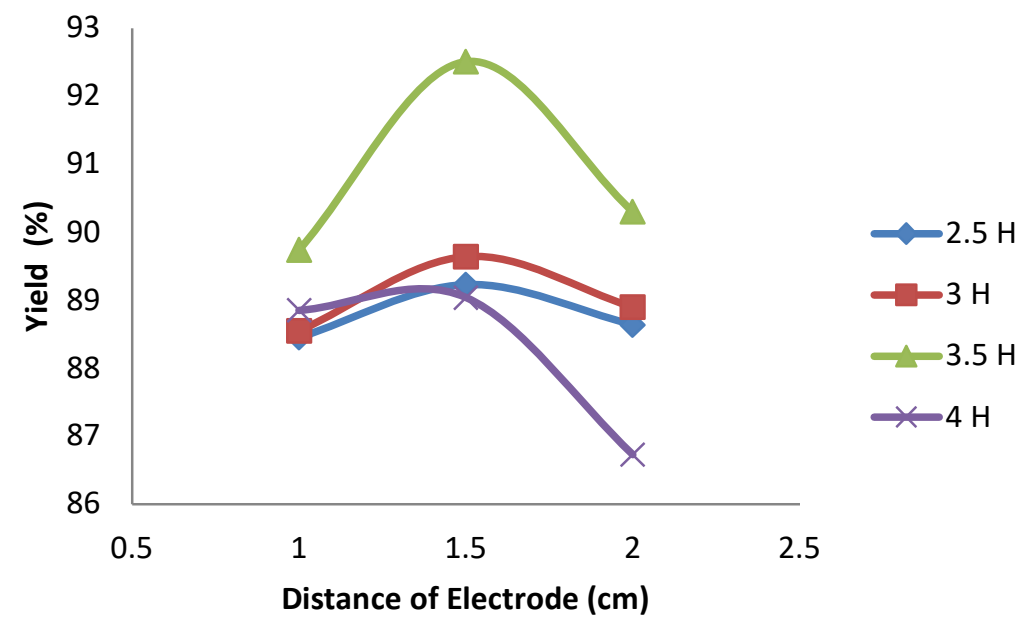

Fig.-1: Related of Electrode Distance to Biodiesel Yield

Electrode distance effect to biodiesel yield shown in graph 1. At electrode distance of $1-1.5 \mathrm{~cm}$, it proceeded to increase to biodiesel yield but at a distance of $2 \mathrm{~cm}$ was outcome decrease. Both distance electrodes are having an optimum outcome which can be an affected electrode moving. Electrode placement with near position can be the decrease of efficiency because it will proceed short electricity by an electron. That process resulted in a bother of reaction form. Other than that, further electrode distance resulted in electrical resistance more than electrolytes, a decrease of conductivity, and gas vesicle accumulation at the electrode area. This accumulation is the outcome to be inefficient process. ${ }^{12}$

\section{Electrolysis Time Effect to Biodiesel Yield}

The time of electrolysis is representative of triglyceride transesterification and PSO changes to biodiesel. The increase of electrolysis time will be added electron transfer each electrode. This process proceeded $\mathrm{OH}^{-}$ an amount that reacted with methanol to create a methoxide ion. This ion will be reacted with triglyceride and then is the outcome of methyl ester or biodiesel. The outcome of time variation of $2.5-3.5$ hours, it will be adding biodiesel yield such as shown in Fig.-2.

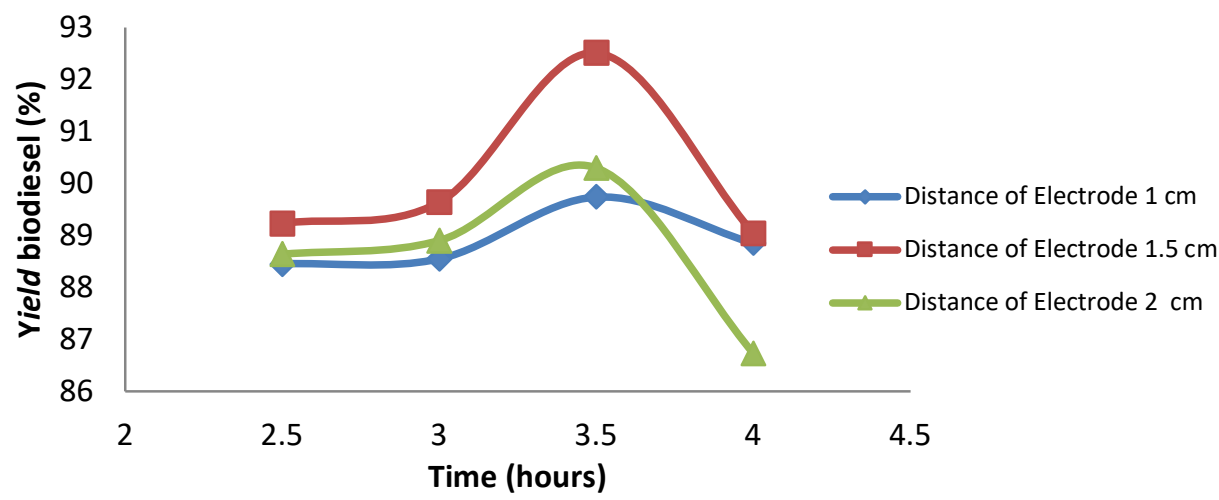

Fig.-2: Graphic of Electrolysis Time to Biodiesel Yield

Accurately time electrolysis achieves at 4 hours, biodiesel yield will decline. It was the proceeding of equilibrium reaction which this reaction achieved. Furthermore, it is not gaining the result but it will be a 
RASĀYAN J. Chem.

Vol. 13 | No. 4 |2401-2404| October - December | 2020

decrease in biodiesel yield. This yield will decline at 4 hours because there is another reaction. That reaction took more than 4 hours, it will be the outcome of glycerol at a product. Another effect, the reaction will be moving to product creation bigger than usual.

Electrode distance and time of electrolysis effect to result of methoxide ion. This circumstance is certainly making electrical resistance to the electrolysis process. If electrical resistance is bigger, it can be less outcome of electron amount which it works electron transfer. Hydroxyl ion $\left(\mathrm{OH}^{-}\right)$will be decline that ion will impact to methanol. This reaction resulted in a methoxide ion. The most factor which will give high concern is electrical resistance on the electrolysis process.

According to the discussion above, transesterification process time and electrode distance related to getting optimum biodiesel yield. In this experiment, the optimum result of electrolysis time at 3.5 hours and electrode distance maximum is $1.5 \mathrm{~cm}$. this condition can get biodiesel yield of $92.51 \%$.

\section{Biodiesel Quality Standard Analyze}

Biodiesel characterization needed to prove that result was filling the quality standard of fuel. Table-2 shown biodiesel characterization which it took electrolysis time of 3.5 hours and electrode distance is 1.5 hours. All of the research proceed shows all parameters to suit Standard Nasional Indonesia No. 7182 (2015).

Table-2: Biodiesel Characterization of PSO proceeds electrolysis process which time of the process is 2.5 hours and the distance electrode is $1.5 \mathrm{~cm}$.

\begin{tabular}{c|c|c}
\hline Parameter & SNI 7182 $(2015)$ & Result \\
\hline Density & $850 \mathrm{~kg} / \mathrm{m}^{3}-890 \mathrm{~kg} / \mathrm{m}^{3}$ & $883.40 \mathrm{~kg} / \mathrm{m}^{3}$ \\
\hline Viscosity & $2.3 \mathrm{cSt}-6.0 \mathrm{cSt}$ & $4.8869 \mathrm{cSt}$ \\
\hline Acidic value & $\leq 0.5 \mathrm{mg}-\mathrm{KOH} / \mathrm{g}$ & $0.4405 \mathrm{mg}-\mathrm{KOH} / \mathrm{g}$ \\
\hline Flash Point & $\geq \mathrm{Min} 100^{\circ} \mathrm{C}$ & $170^{\circ} \mathrm{C}$ \\
\hline
\end{tabular}

\section{CONCLUSION}

The highest biodiesel yield proceeded at electrode distance is $1.5 \mathrm{~cm}$ and the transesterification process is 3.5 hours. This result is $92,51 \%$. Biodiesel characterization resulted was at the density of $883.40 \mathrm{~kg} / \mathrm{m} 3$, the kinematic viscosity of $4.8869 \mathrm{cSt}$, the acidic value of $0.4405 \mathrm{mg} \mathrm{KOH} / \mathrm{grams}$ and the flashpoint of $170^{\circ} \mathrm{C}$. This result filled by SNI No. 7182:2015

\section{REFERENCES}

1. E. B. Moushoul, K. Farhadi, Y. Mansourpanah, A.M. Nikbakht, R. Molaei, M. Forough, Fuel, 164, 119(2015), DOI:10.1016/j.fuel.2015.09.067.

2. Abdullah, R.N.R. Sianipar, D. Ariyani, I.F. Nata, Sustainable Environment Research, 27(6), 291(2017), DOI: $10.1016 /$ j.serj.2017.07.002.

3. Irvan, B. Trisakti1, S. Maulina, H. Daimon, Rasayan Journal of Chemistry, 11(1), 378(2018), DOI: 10.7324/RJC.2018.1112028.

4. D.Y.C. Leung, X. Wu, M.K.H. Leung, Applied Energy, 87(4), 1083(2010), DOI: 10.1016/j.apenergy.2009.10.006

5. S. Liu, T.Mc. Donald, Y. Wang, Fuel, 89(10), 2735(2010), DOI: 10.1016/j.biotechadv.2010.03.002

6. E.F. Aransiola. T.V. Ojumu. O.O. Oyekola. T.F. Madzimbamuto. D.I.O. Ikhu-Omoregbe, Biomass and Bioenergy, 61, 276(2013), DOI:10.1016/j.biombioe.2013.11.014

7. G. Guan and K. Kusakabe, Chemical Engineering Journal, 153(1), 159(2009), DOI: 10.1016/j.cej.2009.06.005.

8. L. Fereidooni and M. Mehrpooya, Energy Conversion and Management, 147, 145(2017), DOI: 10.1016/j.enconman.2017.05.051

9. D. Irawan, Z. Arifin, Fitriyana, C. Olivia, M. Nopal, International Journal of Scientific \& Technology Research, 8(9), 465(2019).

10. M.C. Hsiao, J.Y. Kuo, P.H. Hsieh, S.S. Hou, Journal of Energies, 11(9), 2298(2018), DOI: $10.3390 /$ en1 1092298

11. R. Moeksin, M.Z. Shofahaudy, D.P. Warsito, Jurnal Teknik Kimia, 23, 17(2017)

12. K. Mazloomi, N. Sulaiman, H. Moayedi, International Journal of Electrochemical Science, 7, $3314(2012)$

[RJC-6005/2020] 